\title{
Investigation of An Electronically Controlled Hybrid Hydrogen-Gasoline Engine Powered Passenger Car
}

\author{
L.J. Hao \\ Key Laboratory of operation safety technology on transport \\ vehicles \\ Ministry of Transport \\ Beijing, China \\ School of Mechanical Engineering \\ Beijing Institute of Technology \\ Beijing, China \\ C.X. Ren \\ Key Laboratory of operation safety technology on transport \\ vehicles \\ Ministry of Transport \\ Beijing, China
}

\author{
M. Chen \\ School of Mechanical Engineering \\ Beijing Institute of Technology \\ Beijing, China \\ C.W. Ji \\ College of Environmental and Energy Engineering \\ Beijing University of Technology \\ Beijing, China
}

\begin{abstract}
Hydrogen is very promising as engine fuel due to its excellent combustion and emission characteristics. In order to improve the emission of a spark-ignited gasoline engine car a set of hydrogen injection system was added to its gasoline engine and the engine can be fuelled with gasoline, hydrogen or both. An electronic control system was developed and applied to control the injection timings and duration of hydrogen and gasoline. The basic composition of the control system and the fuel injection control strategy of the hybrid hydrogen-gasoline engine were studied in this paper. Finally the tailpipe emission of the hybrid hydrogen-gasoline powered car was tested over the NEDC driving cycle, and compared with that of the original gasoline car. The experimental results showed that the emission of the hybrid hydrogen-gasoline powered car is improved and can meet ChinaIV emission standard.
\end{abstract}

Keywords-hydrogen; gasoline; electronic control engine; NEDC; emission

\section{INTRODUCTION}

In recent years the toxic exhaust emissions from automobiles have aroused more and more concerns due to their negative effects on humans' health and environment. As a clean alternative fuel hydrogen has shown a bright and promising future as engine fuel due to its extremely good combustion characteristics $[1,2]$. However, the pure hydrogen engines are not practical due to the inconvenience of hydrogen fuel supply, limited vehicle travel distance and their abnormal combustion tendency. And the low volumetric energy density of hydrogen-air combustible mixture also results in the lower engine power output for the pure hydrogen engines. Ganesh et al. [3] experimentally studied the performance of a hydrogen engine. The test results showed that the power output of the hydrogen engine was $20 \%$ lower than that of the gasoline engine. HC and $\mathrm{CO}$ emissions were negligible, but NOx emission of the hydrogen engine was almost four times higher than that emitted from the gasoline engine. On the other hand by adding a portion of hydrogen to the traditional gasoline engine the hydrogen can improve the engine combustion process due to its wide flammability, low ignition temperature and high burning speed, and the hydrogen-added gasoline engine can gain better performance than the original mono gasoline-fuelled engines [4-6].

In this study, an electronically controlled hydrogen portinjection system was added to the original gasoline engine while keeping the gasoline control system unchanged. A hybrid electronic control system was developed and used to control the injection timings and duration of hydrogen and gasoline. The composition of the control system and the hybrid hydrogen-gasoline injection control strategy were discussed in this paper. Finally the hybrid hydrogen-gasoline fuelled car was tested over the NEDC driving cycle in order to investigate its emission characteristics.

\section{SCHEMATIC OF THE CONTROL SYSTEM FOR THE HYBRID HYDROGEN-GASOLINE FUELLED ENGINE}

The hybrid hydrogen-gasoline fuelled engine was refitted from an original multi-point injection gasoline engine. An electronically controlled hydrogen injection system was designed and added to the gasoline engine while keeping the control function of the original gasoline injection system. A hybrid electronic control unit (HECU) was applied to govern the injection timings and durations of hydrogen and gasoline. The schematic of the hybrid hydrogen-gasoline engine control system is depicted in Fig. 1. 


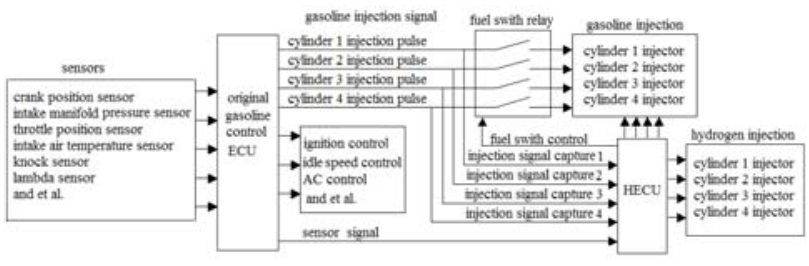

FIGURE I. SCHEMATIC OF THE HYBRID HYDROGEN-GASOLINE ENGINE CONTROL SYSTEM.

The original gasoline ECU controls the gasoline injection quantity, ignition timing, idle speed and other actuators by monitoring various sensors, which include crank position sensor, intake manifold absolute pressure sensor, throttle position sensor, intake air temperature sensor, knock sensor, lambda sensor, and et al. when the engine needs to operate on hydrogen, the HECU switches the gasoline fuel to the hydrogen fuel, vice verse the HECU can also switch the hydrogen fuel to the gasoline fuel.

The HECU, located in the engine compartment, must be capable of high speed computation and management. Thus a Freescale MC9S12DP256 microchip computer acts as the HECU central processor and connects the engine control system wiring by means of a multiple 37-pin connector.

The hydrogen supply system consists of a 12L hydrogen cylinder, hydrogen supply cut-off valve, pressure regulator, hydrogen injectors, and et al. The hydrogen cylinder was placed in the trunk and supplies hydrogen onboard, and the hydrogen is stored at a pressure of $400 \mathrm{kPa}$ in the hydrogen cylinder.

\section{FUEL INJECTION CONTROL STRATEGY FOR THE HYBRID HYDROGEN-GASOLINE FUELLED ENGINE}

When the gasoline engine starts under cold weather condition, a large portion of regulated and unregulated gaseous pollutants is emitted during cold-start period, especially within initial several minutes before the catalyst reaches its optimal operating condition $[7,8]$. This brings a big challenge to the gasoline car for type approval emission test. To reduce the engine cold start emission is very important not only for type approval emission test but also for environmental protection.

Based on our former studies on the $\mathrm{A} / \mathrm{F}$ control strategies for the hybrid hydrogen-gasoline fuelled engine[9-12], starting engine by pure hydrogen can greatly reduce starting time due to the hydrogen's flammable and fast burn characteristics, and also largely reduce $\mathrm{HC}$ and $\mathrm{CO}$ emissions for its carbon-free combustion. But when the engine warms up, hydrogen addition will inevitably increase the tendency of NOx formation. So the optimized control of hydrogen addition should be realized. In this study, the engine was fuelled with pure hydrogen for the first 7 seconds since start-up and operated at lean combustion conditions, and then the injected hydrogen quantity gradually decreased while the injected gasoline increased proportionally in the following 4 seconds, after the fuel transition the engine turned to run on pure gasoline and operated near the theoretical air/fuel ratio in order to keep the three-way catalyst in optimal operation condition to clean the three exhaust gas components simultaneously and efficiently.

\section{VEHICLE EMISSION TEST}

\section{A. Testing Facilities and Equipment}

The New European Driving Cycle (NEDC) is the legislation testing cycle for the emission type approval of light duty vehicles in Europe. The hybrid hydrogen-gasoline engine-powered passenger car was tested over the NEDC driving Cycle in order to evaluate its emission performance. The schematic of the testing system for the hybrid hydrogengasoline fuelled passenger car is shown in Fig. 2.

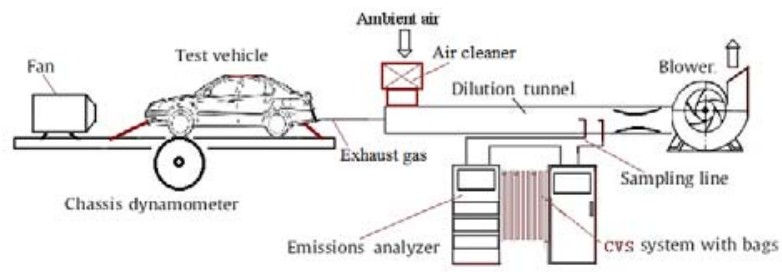

FIGURE II. THE SCHEMATIC OF EMISSION TEST SYSTEM FOR THE PASSENGER CAR.

The test vehicle is a $1.8 \mathrm{~L}$ gasoline passenger car manufactured by Hyundai Motors. The original gasoline fuelled vehicle could meet the China-II emission legislation limits. The hydrogen injection system and the hybrid electronic control unit (HECU) were installed on this Hyundai gasoline passenger car. The HECU is applied to control the injection timings and durations of hydrogen and gasoline, and the transition of fuel supply.

The test vehicle was fastened on the chassis dynamometer test bench and its total resisting forces while driving was simulated and exerted by an Ono Sokki PECD-9400 chassis dynamometer. A Horiba CVS sampling system and MEXA$7200 \mathrm{H}$ emission analyzers were applied to measure the test vehicle tailpipe emissions including $\mathrm{HC}, \mathrm{CO}$ and NOx.

\section{B. Test Protocols}

First, the vehicle was driven over NEDC driving cycle for pre-treatment and then soaked in the lab for at least 12 hours under the temperature of $20-30^{\circ} \mathrm{C}$. The emission of the original gasoline vehicle was tested first over NEDC testing cycle, and the vehicle was soaked at least 12 hours again. Then the vehicle ran on hydrogen and gasoline according to the control strategy we have concluded before, from start-up the engine was fuelled with pure hydrogen for the first 7 seconds, then 4 seconds of transition from hydrogen to gasoline, after 11 seconds the engine turned to run on pure gasoline.

Before vehicle emission test, the MEXA-7200H emission analyzers warm up at least 30 minutes. And all experimental instruments need to be calibrated and functioned according to the NEDC emission test requirements.

During NEDC testing, the diluted exhaust gas was sampled and collected in the CVS sampling bags and analyzed by the MEXA-7200H emission analyzers after the test. While a partial of diluted exhaust gas was sampled via a direct sampling line and measured simultaneously during the 
experiment process. Based on the total diluted exhaust gas volume and the concentrations and densities of various exhaust gas components, the mass emissions of different exhaust pollutants can be calculated.

\section{Results and Discussion}

The vehicle emission test results over the two NEDC test cycles are listed in Table 1, in which China-II, China-III and China IV emissions limits are also given.

TABLE I. VEHICLE EMISSION TEST RESULTS

\begin{tabular}{|c|c|c|c|}
\hline & $\begin{array}{c}\text { CO } \\
\mathbf{g} / \mathbf{k m}\end{array}$ & $\begin{array}{c}\text { HC } \\
\mathbf{g} / \mathbf{k m}\end{array}$ & $\begin{array}{c}\mathbf{N O x} \\
\mathbf{g} / \mathbf{k m}\end{array}$ \\
\hline Test 1 & 1.61 & 0.22 & 0.019 \\
\hline Test 2 & 0.61 & 0.079 & 0.048 \\
\hline China-II emissions limits & 2.2 & \multicolumn{2}{|c|}{$\mathrm{HC}+\mathrm{NOx} 0.5$} \\
\hline $\begin{array}{c}\text { China-III emissions } \\
\text { limits }\end{array}$ & 2.3 & 0.2 & 0.15 \\
\hline $\begin{array}{c}\text { China-IV emissions } \\
\text { limits }\end{array}$ & 1.0 & 0.1 & 0.08 \\
\hline
\end{tabular}

The emission test results showed that the $\mathrm{CO}$ and $\mathrm{NOx}$ emission level of the original gasoline vehicle can meet ChinaIII emission limits, but its HC exhaust emission is a little higher than the HC legislation limit of China-III emission standard. In order to start successfully the original gasoline engine has to be supplied more gasoline to form rich air-fuel combustible mixture in cylinder during cold start. This leads to incomplete combustion and increased $\mathrm{HC}$ and $\mathrm{CO}$ emission. In Test 2, the engine was started on pure hydrogen, and transferred to run on gasoline after 11 seconds. Since the combustion of hydrogen does not generate carbon-related emissions, the CO and $\mathrm{HC}$ emissions in Test 2 were much lower than that of the original engine. The emission level of the hybrid hydrogen-gasoline engine-powered passenger car can meet China-IV emissions limits.

\section{CONCLUSIONS}

A hybrid hydrogen-gasoline fuelled car was refitted from an original electronic control gasoline car. The hybrid electronic control unit designed in this paper can govern the injection timings and durations of hydrogen and gasoline according to the engine operation requirements. Based on the emission results over NEDC driving cycle, the emission level of the hybrid hydrogen-gasoline fuelled car is improved compared with the original gasoline car, and can meet ChinaIV emissions legislation limits.

\section{ACKNOWLEDGEMENTS}

This work was supported by the Opening Project of Key Laboratory of operation safety technology on transport vehicles, Ministry of Transport, PRC.

\section{REFERENCES}

[1] Das, L.M., Hydrogen Engines: A Review of the Past and A Look into the Future, International Journal of Hydrogen Energy, 15: pp.425443,1990.

[2] Karim, G.A., Hydrogen as a Spark Ignition Engine Fuel, International Journal of Hydrogen Energy, 28: pp. 569-577,2003.
[3] Ganesh RH, Subramanian V, Balasubramanian V, Mallikarjuna JM, Ramesh A, Sharma RP. Hydrogen fuelled spark ignition engine with electronically controlled manifold injection: an experimental study. Renew Energy, 33:pp.1324-1333, 2008

[4] Akansu SO, Kahraman N, Ceper B. Experimental study on a spark ignition engine fuelled by methane-hydrogen mixtures. International Journal of Hydrogen Energy, 32: pp.4279-84, 2007.

[5] Ji C, Wang S. Effect of hydrogen addition on the idle performance of a spark ignited gasoline engine at stoichiometric condition. International Journal of Hydrogen Energy, 34: pp.3546-3556, 2009.

[6] Ji C, Wang S, Wang, Zhang B. Combustion and emissions characteristics of a hybrid hydrogen-gasoline engine under various loads and lean conditions. International Journal of Hydrogen Energy, 35(5): pp.5714-5722,2010.

[7] Clairotte M, Adam TW, Zardini AA, Manfredi U, Martini G, Krasenbrink A, et al. Effects of low temperature on the cold start gaseous emissions from light duty vehicles fuelled by ethanol-blended gasoline. Appl Energy,102:pp.44-54 2013.

[8] Dardiotis C, Martini G, Marotta A, Manfredi U. Low-temperature coldstart gaseous emissions of late technology passenger cars. Applied Energy, 111: pp.468-478,2013.

[9] Ji C, Wang S. Effect of hydrogen addition on lean burn performance of a spark-ignited gasoline engine at $800 \mathrm{rpm}$ and low loads. Fuel 2011;90:1301-1304.

[10] Wang S, Ji C, Zhang M, Zhang B. Reducing the idle speed of a sparkignited gasoline engine with hydrogen addition. International Journal of Hydrogen Energy, 35: pp.10580-10588, 2010.

[11] Ji C, Wang S. Effect of hydrogen addition on idle performance of a sparkignited gasoline engine at lean conditions with a fixed spark advance. Energy Fuel, 23: pp.4385-4394, 2009.

[12] Ji C, Wang S. Experimental Study on Combustion and Emissions Characteristics of a Spark Ignition Engine Fuelled with GasolineHydrogen Blends. Energy \& Fuels, 23(6): pp.2930-2936, 2009. 